\title{
ACTUAL AND POTENTIAL PHOTOSYNTHETIC RATES OF TROPICAL CROP SPECIES
}

\author{
FÁBIO M. DA MATTA ${ }^{1 *}$, RODOLFO A. LOOS $^{1}, \operatorname{RODRIGO~RODRIGUES~}^{1}$ AND \\ RAIMUNDO S. BARROS ${ }^{1}$
}

Departamento de Biologia Vegetal, Universidade Federal de Viçosa, 36571-000 Viçosa, MG, Brasil

\begin{abstract}
The actual $(A)$ and potential $\left(A_{\mathrm{pot}}\right)$ photosynthetic rates of $\mathrm{C}_{3}$ and $\mathrm{C}_{4}$ tropical crop species grown under greenhouse conditions was compared. The following species were investigated: Oryza sativa, Phaseolus vulgaris, Glycine max, Helianthus annuus, Gossypium hirsutum, Manihot esculenta, Theobroma cacao, Coffea arabica, Hevea brasiliensis, and Eucalyptus urophylla $\times$ E. grandis, all from the $\mathrm{C}_{3}$ group, and Amaranthus sp., Panicum maximum, Pennisetum purpureum, Zea mays and Saccharum officinarum, from the $\mathrm{C}_{4}$ group. $A$, determined under non-limiting light at ambient temperature and $\mathrm{CO}_{2}$, was measured with an infrared gas analyser, whilst $A_{\text {pot }}$, determined under saturating light and $\mathrm{CO}_{2}$ at an optimal temperature $\left(35^{\circ} \mathrm{C}\right.$ for all species), was gauged with a gas-phase oxygen electrode. On an area basis, $A$ varied from 5.0 up to $26.3 \mu \mathrm{mol} \mathrm{CO} \mathrm{Cm}^{-2} \mathrm{~s}^{-1}$, whilst $A_{\text {pot }}$ was very similar in 14 of the 15 species, with an average rate of $35.0 \pm 2.4 \mu \mathrm{mol} \mathrm{O} \mathrm{O}^{-2} \mathrm{~s}^{-1}$. The value of $A_{\text {pot }}$ in $T$. cacao was approximately half the mean of the remaining species. On a mass basis, variations in $A$ were much larger, and differences in $A_{\text {pot }}$, although not large, emerged. The overall mean $A_{\text {pot }}$ per unit mass in the four tree species was $28.0 \pm$ $2.2 \mu \mathrm{mol} \mathrm{O} \mathrm{g}^{-1} \mathrm{~min}^{-1}$ against $44.6 \pm 5.8 \mu \mathrm{mol} \mathrm{O} \mathrm{g}^{-1} \mathrm{~min}^{-1}$ in the remaining species. As a whole, the results evidenced a conservative behaviour of the photosynthetic apparatus to fix $\mathrm{CO}_{2}$ amongst the species investigated, despite the large differences in $A$ among them.
\end{abstract}

ADDITIONAL INDEX TERMS: Carbon assimilation rate, photosynthetic oxygen evolution, specific leaf area.

\section{TAXAS FOTOSSINTÉTICAS ATUAL E POTENCIAL DE ESPÉCIES TROPICAIS CULTIVADAS}

RESUMO - Compararam-se as taxas fotossintéticas atual $(A)$ e potencial $\left(A_{\text {pot }}\right)$ de espécies tropicais $\mathrm{C}_{3} \mathrm{e}$ $\mathrm{C}_{4}$ cultivadas sob condições de casa-de-vegetação. Foram estudadas as seguintes espécies: Oryza sativa, Phaseolus vulgaris, Glycine max, Helianthus annuus, Gossypium hirsutum, Manihot esculenta, Theobroma cacao, Coffea arabica, Hevea brasiliensis, e Eucalyptus urophylla $\times$ E. grandis, todas do grupo $\mathrm{C}_{3}$, e Amaranthus sp., Panicum maximum, Pennisetum purpureum, Zea mays e Saccharum officinarum, do grupo $\mathrm{C}_{4}$. $A$, determinada sob alta irradiância e temperatura e $\mathrm{CO}_{2}$ ambientes, foi medida com um analisador de gases a infravermelho, enquanto $A_{\text {pot, }}$, determinada sob luz e $\mathrm{CO}_{2}$ saturantes e à temperatura ótima $\left(35^{\circ} \mathrm{C}\right.$ para todas as espécies), foi medida com um eletrodo de oxigênio de fase gasosa.

Received: 14/11/2000 - Accepted: 3/4/2001

1. Departamento de Biologia Vegetal, Universidade Federal de Viçosa, 36571-000 Viçosa, MG, Brasil.

* Corresponding author (e-mail, fdamatta@mail.ufv.br). 
Em base de área, $A$ variou desde 5,0 até $26,3 \mu \mathrm{mol} \mathrm{CO}_{2} \mathrm{~m}^{-2} \mathrm{~s}^{-1}$, enquanto $A_{\text {pot }}$ foi similar em 14 das 15 espécies avaliadas, com uma taxa média de $35.0 \pm 2.4 \mu \mathrm{mol} \mathrm{O}_{2} \mathrm{~m}^{-2} \mathrm{~s}^{-1}$. Observou-se um padrão diferencial em T. cacao, em que $A_{\text {pot }}$ decresceu, aproximadamente, em 50\% em relação a $A_{\text {pot }}$ das demais espécies estudadas. Em base de massa, as variações em $A$ foram bem maiores e diferenças em $A_{\text {pot }}$, embora não expressivas, puderam ser observadas. Os valores médios de $A_{\text {pot }}$ por unidade de massa, nas quatro espécies lenhosas, foi $28.0 \pm 2.2 \mu \mathrm{mol} \mathrm{O} \mathrm{O}^{-1} \min ^{-1}$, contra $44.6 \pm 5.8 \mu \mathrm{mol} \mathrm{O} \mathrm{O}_{2} \mathrm{~g}^{-1} \mathrm{~min}^{-1}$ nas espécies remanescentes. Como um todo, os resultados evidenciaram um comportamento conservado do aparelho fotossintético, em termos de fixação do $\mathrm{CO}_{2}$, nas espécies estudadas, a despeito das largas diferenças em $A$ entre elas.

TERMOS ADICIONAIS PARA INDEXAÇÃO: Área foliar específica, evolução do oxigênio fotossintético, taxa de assimilação do carbono.

\section{INTRODUCTION}

Large differences in the actual photosynthetic rates $(A)$, termed herein as the maximum net rate of carbon uptake under nonlimiting photosynthetic photon flux (PPF) at ambient temperature and $\mathrm{CO}_{2}$ in healthy, unstressed plants, exist within the plant kingdom. On an area basis, values of $A$ cover a wide range, from less than 2 up to $70 \mu \mathrm{mol} \mathrm{CO}_{2} \mathrm{~m}^{-2} \mathrm{~s}^{-1}$ (Larcher, 1995), and may even achieve values as high as $80 \mu \mathrm{mol} \mathrm{CO}_{2} \mathrm{~m}^{-2} \mathrm{~s}^{-1}$, as in Amaranthus retroflexus (Pearcy and Ehleringer, 1984). However, it is often difficult to make meaningful comparisons of photosynthetic rates as determined by different investigators because of variations in measurement techniques and methods of expressing photosynthetic rates, in addition to preconditioning effects of environment on leaf anatomy (Kozlowski and Pallardy, 1997).

Comparative studies of $\mathrm{C}_{3}$ and $\mathrm{C}_{4}$ plants have generally shown that the latter, in their native habitats, exhibit higher photosynthetic rates. Such a behaviour is largely a result of a suite of biochemical, physiological and morphological components collectively functioning to concentrate $\mathrm{CO}_{2}$ in vascular bundle sheath cells (Pearcy and Ehleringer, 1984). On the other hand, the majority of $\mathrm{C}_{3}$ plants, particularly woody species, display low photosynthetic performances (Körner, 1995; Larcher, 1995). However, some agricultural $C_{3}$ crop plants may achieve photosynthetic rates near or similar to those of $\mathrm{C}_{4}$ species, possibly due to successful breeding (Larcher, 1995). On biochemical grounds, the causes of the specific differences in $A$ lie in the capacity of ribulose-1,5bisphosphate (RuBP) carboxylase to consume RuBP, the capacity of the thylakoid and Calvin cycle reactions to regenerate $\mathrm{RuBP}$, and the capacity of starch and sucrose synthesis to regenerate inorganic phosphate from phosphorylated photosynthetic intermediates. Each of these processes represents major points of direct interaction with the environment beyond the photosynthetic apparatus (Sage and Reid, 1994).

Some investigations have been conducted in order to characterise the photosynthetic performance of a given species or a community. In several cases a high correlation between leaf nitrogen concentration and $A$ of different species has been found (Field and Mooney, 1986; Chazdon and Field, 1987; Evans, 1989; Reich and Walters, 1994; Woodward and Smith, 1995). Other studies have shown a high correlation between leaf conductance and $A$ within diverse vegetation types distributed world-wide (Körner et al., 1979; Körner, 1995). Comparatively with $A$, to our knowledge less is known about the characterisation of potential photosynthetic rates $\left(A_{\text {pot }}\right)$, which herein represent the rate of net photosynthesis as measured at optimal temperature under saturating PPF and $\mathrm{CO}_{2}$. Previous results obtained in our laboratory with some tropical species revealed very similar values of $A_{\text {pot }}$ among species, despite large differences in $A$ among them. It remains to be 
ascertained, therefore, whether $A_{\text {pot }}$ shows a conservative pattern among plants of different photosynthetic performances. In this preliminary work, $A$ and $A_{\text {pot }}$ were measured in $14 \mathrm{C}_{3}$ and $\mathrm{C}_{4}$ tropical crop species, including herbaceous and woody plants which differ widely in growth habit, leaf anatomy and photosynthetic capacity. For comparison, a $\mathrm{C}_{4}$ dicot, Amaranthus sp., a weed plant commonly occurring in disturbed habitats and agricultural fields, was also investigated.

\section{MATERIAL AND METHODS}

\section{Plant material and growth conditions}

Photosynthetic measurements were conducted on ten $\mathrm{C}_{3}$ species, including one monocot, rice (Oryza sativa L.), four herbaceous dicots, common bean (Phaseolus vulgaris L.), soybean (Glycine max [L.] Merr.), sunflower (Helianthus annuus L.) and cotton (Gossypium hirsutum L.), one shrub, cassava (Manihot esculenta Crantz), and four tree dicot plants, cacao (Theobroma cacao L.), coffee (Coffea arabica L.), rubber (Hevea brasiliensis [H.B.K.] Muell-Arg.) and eucalyptus (Eucalyptus urophylla Blake $\times E$. grandis Hill ex Maiden). Five $\mathrm{C}_{4}$ species were also used, including one dicot, pigweed (Amaranthus sp.), and four monocots, panic grass (Panicum maximum Jacq.), millet (Pennisetum purpureum Schumach), maize (Zea mays L.) and sugarcane (Saccharum officinarum L.). Eucalyptus, cassava and sugarcane were grown from stem cuttings, and the remaining species were raised from seeds.

The experiment was carried out in Viçosa $\left(20^{\circ} 45^{\prime} \mathrm{S}, 650 \mathrm{~m}\right.$ a.s.1.), Brazil, in a greenhouse at ambient $\mathrm{CO}_{2}$ without temperature control. At 13h00, air temperature inside the greenhouse was up to $7{ }^{\circ} \mathrm{C}$ higher than outside air. Incoming PPF was transmitted by $60 \%$, as determined in midsummer. Plants were grown in 6-L plastic pots containing a 3:1 (v:v) mixture of soil and manure. In order to get uniform plants, the seedlings were thinned after germination. Plants were watered daily and flushed once a week with $400 \mathrm{~mL}$ of full strength Hoagland solution (Hoagland and Arnon, 1950). At the time of measurements, the herbaceous plants, employed prior to flowering, were four to six weeks old, and the young tree species were eight to 13 months old. Cassava was approximately two months old. All measurements were made in late spring or in summer on a youngest, completely expanded mature leaf or leaflet.

\section{Leaf gas exchange parameters}

The stomatal conductance to water vapour $\left(g_{\mathrm{s}}\right)$ and $A$ were measured on attached leaves at ambient $\mathrm{CO}_{2}$ partial pressure (about 36 $\mathrm{Pa}$ ) using a portable, open-system infrared gas analyser (LCA-4, Analytical Development Co., Hoddesdon, UK). Artificial PPF was supplied by a portable light unit (PLU2-002) containing a dichroic $12 \mathrm{~V}, 20 \mathrm{~W}$ lamp, an air extractor fan and an infrared heat absorbing filter. For $\mathrm{C}_{3}$ species, PPF for saturating photosynthesis was determined from response curves of $A$ to PPF obtained in triplicates for each species; such a saturating PPF varied from $650-750 \mu \mathrm{mol} \mathrm{m} \mathrm{s}^{-2}$ as in cacao and coffee, respectively, to $1700 \mu \mathrm{mol} \mathrm{m} \mathrm{m}^{-2} \mathrm{~s}^{-1}$ as in sunflower. For $\mathrm{C}_{4}$ species, photosynthesis was not fully saturated by employing the maximum attainable PPF of almost $2000 \mu \mathrm{mol} \mathrm{m} \mathrm{m}^{-2} \mathrm{~s}^{-1}$. After fitting the leaf tissue in the Parckinson leaf chamber (PLC4), rates for gas exchange were typically settled within 2-3 min, nearly paralleling stabilisation for internal $\mathrm{CO}_{2}$ values. Gas flow through the leaf chamber was $255 \pm 2 \mu \mathrm{mol} \mathrm{s}{ }^{-1}$. During the measurements $(08 \mathrm{~h} 30-09 \mathrm{~h} 30)$, the air relative humidity and leaf temperature ranged from 74 to $83 \%$, and 24 to $29^{\circ} \mathrm{C}$, respectively.

Potential photosynthetic rates $\left(A_{\mathrm{pot}}\right)$ were measured by oxygen evolution on the same leaves used for $A$ measurements, and determined under saturating $\mathrm{CO}_{2}$ partial pressure (approximately $5 \mathrm{kPa}$ supplied by $0.2 \mathrm{~mL}$ of $1 \mathrm{kmol} \mathrm{m}^{-3} \mathrm{KHCO}_{3}$ ), using a gas-phase oxygen electrode (LD-2 Leaf Chamber, 
Hansatech, Norfolk, UK). PPF was provided by a $200 \mathrm{~W}$ halogen-tungsten bulb mounted in a light source (LS2, Hansatech), which gave little less than $3000 \mu \mathrm{mol} \mathrm{m} \mathrm{m}^{-2} \mathrm{~s}^{-1}$. Saturating PPF at the leaf disk surface $\left(1500-2600 \mu \mathrm{mol} \mathrm{m} \mathrm{m}^{-2} \mathrm{~s}^{-1}\right)$ was adjusted by using neutral density filters. Maximum values of $A_{\text {pot }}$ were measured at $35{ }^{\circ} \mathrm{C}$ following response curves of $A_{\text {pot }}$ to temperature obtained in triplicates for all species. Photosynthetic rates were also measured at saturating light and $\mathrm{CO}_{2}$, but at the same average leaf temperature at which $A$ was measured $\left(A_{\max }\right)$. When possible, $A_{\max }$ and $A_{\text {pot }}$ were determined in $10 \mathrm{~cm}^{2}$ leaf discs; in other cases leaf slices were used, and their total area for photosynthetic rate calculations was measured using an area meter (Area Measurement System, Delta-T Devices, Cambridge, UK). Leaf pieces were then dried to constant mass at $70{ }^{\circ} \mathrm{C}$ in order to determine their specific leaf area (SLA). This parameter was used to express photosynthetic rates per unit mass.

\section{Statistical analysis}

Statistical significance among means obtained from 12 replicates was determined using an ANOVA analysis with a Newman-Keuls' posttest to examine if significant $(P<0.05)$ differences occurred between individual means. In some cases, non-orthogonal contrasts were used in order to confront the overall means from certain groups of plants (e.g., woody species against the remaining ones) using a Scheffé's test.

\section{RESULTS AND DISCUSSION}

As Table 1 shows, $A$ per unit area varied widely among the species investigated, from 5.0 up to $26.3 \mu \mathrm{mol} \mathrm{CO} \mathrm{Cm}^{-2} \mathrm{~s}^{-1}$. As expected, $\mathrm{C}_{4}$ plants exhibited the greatest values of $A$, although sunflower had values similar to plants of the $C_{4}$ group, likely as a result of its high $g_{\mathrm{s}}$ (Table 1) and high amounts of Rubisco (Larcher, 1995). Tree species showed the lowest $A$; in eucalyptus, however, $A$ laid in the range of herbaceous $\mathrm{C}_{3}$ plants, probably as a consequence of its unusually large $g_{\text {s }}$ (Table 1). Differences in $A$, particularly amongst the $\mathrm{C}_{3}$ plants, might be to some extent attributed to differences in $g_{\mathrm{s}}$. Nonetheless, values of $A$, particularly for $\mathrm{C}_{4}$ species, were in general lower than those reported elsewhere (e.g., Gifford, 1974; Ziska and Bunce, 1997). This might in part be a consequence of relatively high temperatures inside the greenhouse.

When rates of photosynthesis were measured at saturating $\mathrm{CO}_{2}\left(A_{\max }\right)$, a different pattern emerged (Table 1). In general, the differences in $A_{\max }$ amongst species were quite narrow, and hence variations in $A_{\max } / A$ ratio were due chiefly to changes in $A$. In $\mathrm{C}_{4}$ plants that ratio ranged from 1.05 to 1.12 , indicating that photosynthesis is almost saturated at ambient $\mathrm{CO}_{2}$. In $\mathrm{C}_{3}$ species $A_{\max } / A$ ratio laid between 1.31 and 5.40 (Table 1). In other words, the rates of photosynthesis under saturating $\mathrm{CO}_{2}$ could be up to $440 \%$ above those found at current atmospheric $\mathrm{CO}_{2}$ partial pressure, as was the case of rubber seedlings. Because $A_{\max }$ was determined under saturating $\mathrm{CO}_{2}$, minimal or no limitation to $\mathrm{CO}_{2}$ diffusion from the outside atmosphere to the carboxylation sites in the chloroplasts and the inhibition of photorespiration are to be expected. These facts undoubtedly contributed to the similarity of values of $A_{\max }$ observed among the species investigated.

It should be stressed that slight differences in leaf temperature between measurements of $A$ and $A_{\max }$ occurred and therefore the values of these parameters among the species examined might not be rigorously comparable. Regardless of the wide variations in $A, A_{\text {pot }}$ (measured at $35^{\circ} \mathrm{C}$ ) per unit area was very similar for all species except for cacao, in which it was significantly lowered $(42 \% ; P<0.0001)$ than the overall mean $A_{\text {pot }}\left(35 \pm 2.4 \mu \mathrm{mol} \mathrm{O} \mathrm{m}^{-2} \mathrm{~s}^{-1}\right)$ of the remaining 14 species (Table 1). The results obtained with cacao should, however, be interpreted cautiously because, as opposed to the other species, cacao seedlings display several shade adaptation attributes. For example, although being cultivated under the same light regime, cacao leaves showed a significant $(P<0.0001)$ doubling in SLA in comparison with the mean SLA from the other three tree species (Table 2). Thus, it is, 
TABLE 1 - Stomatal conductance to water vapour $\left(g_{\mathrm{s}}\right)$, actual photosynthetic rate determined under non-limiting light at ambient temperature and $\mathrm{CO}_{2}(A)$, photosynthetic rate measured under saturating light and $\mathrm{CO}_{2}$ at the same average leaf temperature at which $A$ was measured $\left(A_{\max }\right)$, and potential photosynthetic rate gauged at optimal temperature under saturating light and $\mathrm{CO}_{2}\left(A_{\text {pot }}\right)$ of 15 tropical crop species. Photosynthetic parameters are means of 12 replicates expressed on an area basis. Values followed by the same letter in the column do not differ statistically by the Newman-Keuls' test $(P>0.05)$.

\begin{tabular}{|c|c|c|c|c|c|}
\hline Species & 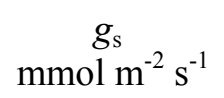 & $\begin{array}{c}A \\
\mu \mathrm{mol} \mathrm{m}{ }^{-2} \mathrm{~s}^{-1}\end{array}$ & $\begin{array}{c}A_{\max } \\
\mu \mathrm{mol} \mathrm{m}^{-2} \mathrm{~s}^{-1}\end{array}$ & $A_{\max } / A$ & $\begin{array}{c}A_{\text {pot }} \\
\mu \mathrm{mol} \mathrm{m} \mathrm{m}^{-2} \mathrm{~s}^{-1}\end{array}$ \\
\hline Maize & $140 \mathrm{gh}$ & $23.4 \mathrm{a}$ & $26.0 \mathrm{ab}$ & 1.11 & $34.7 \mathrm{a}$ \\
\hline Panic grass & $141 \mathrm{gh}$ & $22.3 \mathrm{a}$ & $23.5 \mathrm{ab}$ & 1.05 & $33.0 \mathrm{a}$ \\
\hline Millet & $210 \mathrm{def}$ & $25.0 \mathrm{a}$ & $27.3 \mathrm{ab}$ & 1.09 & $33.4 \mathrm{a}$ \\
\hline Sugarcane & $164 \mathrm{fg}$ & $24.0 \mathrm{a}$ & $25.2 \mathrm{ab}$ & 1.05 & $33.9 \mathrm{a}$ \\
\hline Pigweed & 209 def & $26.3 \mathrm{a}$ & $29.4 \mathrm{ab}$ & 1.12 & $35.0 \mathrm{a}$ \\
\hline Sunflower & $585 \mathrm{a}$ & $24.6 \mathrm{a}$ & $32.2 \mathrm{a}$ & 1.31 & $38.7 \mathrm{a}$ \\
\hline Soybean & 272 cde & $18.3 \mathrm{bc}$ & $25.0 \mathrm{ab}$ & 1.37 & $34.0 \mathrm{a}$ \\
\hline Common bean & $203 \mathrm{ef}$ & $16.3 \mathrm{~cd}$ & $31.9 \mathrm{a}$ & 1.96 & $37.5 \mathrm{a}$ \\
\hline Rice & $374 b$ & $10.3 \mathrm{ef}$ & $25.7 \mathrm{ab}$ & 2.50 & $31.1 \mathrm{a}$ \\
\hline Cotton & $230 \mathrm{def}$ & $18.2 \mathrm{c}$ & $31.8 \mathrm{a}$ & 1.75 & $39.3 \mathrm{a}$ \\
\hline Cassava & $198 \mathrm{fg}$ & $13.7 \mathrm{de}$ & $23.1 \mathrm{bc}$ & 1.69 & $35.7 \mathrm{a}$ \\
\hline Eucalyptus & $320 \mathrm{bcd}$ & $14.4 \mathrm{~cd}$ & $26.1 \mathrm{ab}$ & 1.81 & $33.4 \mathrm{a}$ \\
\hline Coffee & $88 \mathrm{hi}$ & $5.9 \mathrm{~g}$ & $23.8 \mathrm{ab}$ & 4.03 & $33.1 \mathrm{a}$ \\
\hline Rubber tree & $67 \mathrm{i}$ & $5.0 \mathrm{~g}$ & $27.0 \mathrm{ab}$ & 5.40 & $37.3 \mathrm{a}$ \\
\hline Cacao & $120 \mathrm{hi}$ & $6.9 \mathrm{fg}$ & $14.7 \mathrm{c}$ & 2.13 & $20.4 \mathrm{~b}$ \\
\hline
\end{tabular}


TABLE 2 - Specific leaf area (SLA) of 15 tropical species. Values are means of 12 replicates. Means followed by the same letter in the columns do not differ statistically by the Newman-Keuls' test $(P>$ $0.05)$.

\begin{tabular}{lcll}
\hline \multicolumn{1}{c}{ Species } & $\begin{array}{c}\text { SLA } \\
\mathrm{m}^{2} \mathrm{~kg}^{-1}\end{array}$ & \multicolumn{1}{c}{ Species } & $\begin{array}{c}\text { SLA } \\
\mathrm{m}^{2} \mathrm{~kg}^{-1}\end{array}$ \\
\hline Maize & $26.0 \mathrm{a}$ & Rice & $25.2 \mathrm{a}$ \\
Panic grass & $20.7 \mathrm{~b}$ & Cotton & $16.7 \mathrm{~cd}$ \\
Millet & $20.3 \mathrm{~b}$ & Cassava & $20.7 \mathrm{~b}$ \\
Sugarcane & $19.4 \mathrm{bc}$ & Eucalyptus & $13.0 \mathrm{e}$ \\
Pigweed & $21.4 \mathrm{~b}$ & Coffee & $14.6 \mathrm{de}$ \\
Sunflower & $25.0 \mathrm{a}$ & Rubber tree & $11.6 \mathrm{e}$ \\
Soybean & $19.5 \mathrm{bc}$ & Cacao & $25.2 \mathrm{a}$ \\
Common bean & $19.0 \mathrm{bc}$ & & \\
\hline
\end{tabular}

possible that the differential behaviour of $A_{\text {pot }}$ in cacao might be a consequence of its native origin and domestication as understory, shade trees which commonly exhibit low light-saturated photosynthetic rates as a result of low concentration of photosynthetic enzymes and electron transport carriers per unit area (Chazdon et al., 1996). Coffee, on the other hand, in spite of its being originated in natural shady habitats, has a high photosynthetic plasticity, being successfully cultivated at full sun, as in Brazil. With the exception of $A_{\text {pot }}$ for cacao plants, the present results suggest that the photosynthetic potential of individual leaves on an area basis might be a conservative attribute amongst the tropical species here investigated. This pattern should not be attributed to inhibitory effects of high $\mathrm{CO}_{2}$ on respiration (Saralabai et al., 1997), or to respiration per se, as no consistent difference in respiratory rates under either normal or high $\mathrm{CO}_{2}$ was found amongst the species studied (not shown). Although the results obtained here refer to only one developmental stage under one set of growth conditions, in a side experiment the overall rate of $A_{\text {pot }}$ per unit area of field-grown panic grass, millet, sugarcane, pigweed, cassava, coffee and rubber tree was $34.8 \pm 3.9 \mu \mathrm{mol} \mathrm{O}_{2} \mathrm{~m}^{2} \mathrm{~s}^{-1}$, within the same range of values of the present study. A similar rate with hydroponically-cultured common bean at pod formation stage was also found (Lima et al., 2000), supporting the suggestion of a conservative behaviour of $A_{\text {pot }}$.

The most satisfactory basis for expressing photosynthetic rates apparently is leaf area (Kramer and Kozlowski, 1979). However, area-based photosynthesis may be misleading because thick leaves may have more chloroplasts per unit surface than thin leaves; therefore a high rate of $\mathrm{CO}_{2}$ uptake per unit area would be expected, regardless of what would cause the difference in thickness (Kramer and Kozlowski, 1979; Brown, 1994). In fact, mass-based photosynthesis and SLA are usually negatively related to each other (Reich et al., 1991; Prado and Moraes, 1997). Hence, the variations in $A$ per unit area in the present work, in addition to those attributable to $g_{\mathrm{s}}$, could have arisen in part from differences in SLA (Table 2). Nonetheless, $A$ per unit area and SLA showed a trend to change in the same direction, although the correlation between these parameters was not significant $(P>$ 0.05 ). By expressing $A$ per unit mass (Table 3 ), the differences in photosynthetic rates among species were markedly larger than those of $A$ per unit area. On the other hand, the variations of $A_{\text {pot }}$ per unit mass were not so large, with a little more than a doubling between the lowest and the highest value of $A_{\text {pot }}$ obtained with rubber tree and sunflower, respectively (Table 3). Again, this fact also lends support to the hypothesis that $A_{\text {pot, }}$ whether considered on either an area or a mass basis, is a conservative attribute in the species investigated.

By contrasting the tree species with the remaining ones, mass-based $A_{\text {pot }}$ was significantly $(P<0.001)$ lower in the tree species, these producing an overall $A_{\text {pot }}$ of $28.0 \pm 2.2 \mu \mathrm{mol} \mathrm{O}_{2} \mathrm{~g}^{-1}$ $\min ^{-1}$ against $44.6 \pm 5.8 \mu \mathrm{mol} \mathrm{O} \mathrm{g}^{-1} \mathrm{~min}^{-1}$ for the other species. This difference was markedly 
associated with the low SLA in tree species (except cacao). It should be emphasised, however, that low SLA, particularly in woody plants, could result

TABLE 3 - Actual photosynthetic rate determined under non-limiting light at ambient temperature and $\mathrm{CO}_{2}(A)$, and potential photosynthetic rate measured at optimal temperature under saturating light and $\mathrm{CO}_{2}$ $\left(A_{\mathrm{pot}}\right)$ of 15 tropical crop species. Photosynthetic rates are means of 12 replicates expressed on a dry mass basis. Values followed by the same letter in the column do not differ statistically by the Newman-Keuls' test $(P$ $>0.05$ ).

\begin{tabular}{lll}
\hline \multicolumn{1}{c}{ Species } & \multicolumn{1}{c}{$\begin{array}{c}\boldsymbol{A}, \\
\mu \mathbf{m o l ~}^{-1} \mathbf{m i n}^{-1}\end{array}$} & $\begin{array}{c}\boldsymbol{A}_{\mathbf{p o t}}, \\
\mu \mathbf{m o l ~}^{-1} \mathbf{m i n}^{-1}\end{array}$ \\
\hline Maize & $34.3 \mathrm{ab}$ & $53.8 \mathrm{ab}$ \\
Panic grass & $27.6 \mathrm{~d}$ & $41.5 \mathrm{~cd}$ \\
Millet & $30.3 \mathrm{bcd}$ & $40.6 \mathrm{cdef}$ \\
Sugarcane & $29.1 \mathrm{~cd}$ & $39.5 \mathrm{cdef}$ \\
Pigweed & $33.5 \mathrm{abc}$ & $45.0 \mathrm{bc}$ \\
Sunflower & $37.3 \mathrm{a}$ & $56.5 \mathrm{a}$ \\
Soybean & $21.9 \mathrm{e}$ & $40.0 \mathrm{cdef}$ \\
Common bean & $19.0 \mathrm{ef}$ & $42.8 \mathrm{cdef}$ \\
Rice & $15.9 \mathrm{f}$ & $47.2 \mathrm{abc}$ \\
Cotton & $18.2 \mathrm{f}$ & $39.5 \mathrm{cdef}$ \\
Cassava & $17.0 \mathrm{f}$ & $44.4 \mathrm{bc}$ \\
Eucalyptus & $11.1 \mathrm{~g}$ & $26.4 \mathrm{~g}$ \\
Coffee & $5.2 \mathrm{~h}$ & $29.3 \mathrm{efg}$ \\
Rubber tree & $3.5 \mathrm{~h}$ & $26.0 \mathrm{~g}$ \\
Cacao & $10.4 \mathrm{~g}$ & $30.4 \mathrm{defg}$ \\
\hline
\end{tabular}

from an increased investment in nonphotosynthetic tissues throughout their long leaf life-spans (Bongers and Popma, 1990; Reich and Walters, 1994).

In addition, lower SLA and longer leaf life-span have been also associated with (1) potentially different infra-leaf allocation of nitrogen; (2) greater within-leaf shading; and (3) potential diffusion limitations to net carbon uptake (Poorter and Evans, 1998; Reich et al., 1998). These leaf traits might also explain in part why $A$ per unit area varied about 5 -fold in contrast to a 10 -fold variation in $A$ per unit mass among the species studied. Therefore, this might be an important point for explaining the relatively lower $A_{\text {pot }}$ as expressed on a mass basis of tree species.

In conclusion, the results suggest that regardless of the basis used for expressing $A_{\text {pot, }}$, the instantaneous potential photosynthetic rates for carbon fixation were similar among a variety of $\mathrm{C}_{3}$ and $\mathrm{C}_{4}$ tropical crop species studied here. Of course, the similarity in $A_{\text {pot }}$ values within these species was accounted for only by pre-existing components of the photosynthetic apparatus, as other attributes, such as enzyme amounts, would hardly have changed after short-term exposure (5$10 \mathrm{~min}$ ) of leaves to saturating $\mathrm{CO}_{2}$. In any case, the similar values of $A_{\text {pot }}$ might have resulted from a conservative potential to fix $\mathrm{CO}_{2}$. Hence, the large differences in $A$ observed here should be attributed to differential limitations to the overall photosynthetic process, and not to the photosynthetic capacity per se.

\section{ACKNOWLEDGEMENTS}

The authors are indebted to the $\mathrm{CNPq}$ (Conselho Nacional de Desenvolvimento Científico e Tecnológico, Brazil) for fellowships and FAPEMIG (Fundação de Amparo à Pesquisa do Estado de Minas Gerais) for financial support provided to their research projects. Many thanks are due also to Dr. Ernesto Medina for his critical reading of the manuscript and helpful comments. 


\section{REFERENCES}

BONGERS, F. \& POPMA, J. Leaf dynamics of seedlings of rainforest species in relation to canopy gaps. Oecologia, 82:122-127, 1990 .

BROWN, R.H. The conservative nature of crop photosynthesis and the implications of carbon dioxide fixation pathways. In: BOOTE, K.J.; BENNETT, J.M.; SINCLAIR, T.R. \& PAULSEN, G.M. (Eds.) Physiology and determination of crop yield. American Society of Agronomy, Crop Science Society of America, Soil Science Society of America, Madison, 1994. p 211-219.

CHAZDON, R.L. \& FIELD, C.B. Determinants of photosynthetic capacity in six rainforest Piper species. Oecologia, 73:222-230, 1987.

CHAZDON, R.L.; PEARCY, R.; LEE, D. \& FETCHER, N. Photosynthetic responses of tropical forest plants to contrasting light environment. In: MULKEY, S.S.; CHAZDON, R.L. \& SMITH, A.P. (Eds.) Tropical forest plant ecophysiology. Chapman \& Hall, New York, 1996. p 5-55.

EVANS, J.R. Photosynthesis and nitrogen relationships in leaves of $\mathrm{C}_{3}$ plants. Oecologia, 78:9-19, 1989.

FIELD, C.B. \& MOONEY, H.A. The photosynthesis-nitrogen relationship in wild plants. In: GIVINSH, T.J. (Ed.) On the economy of form and function. Cambridge University Press, Cambridge, 1986. p 25-55.

GIFFORD, R.M. A comparison of potential photosynthesis, productivity and yield of plant species with differing photosynthetic metabolism. Australian Journal of Plant Physiology, 1:107-117, 1974.

HOAGLAND, D.R. \& ARNON, D.I. The water culture method for growing plants without soil. California Agricultural Experimental Station Circular, 347:1-32, 1950.
KÖRNER, C. Leaf diffusive conductances in the major vegetation types on the globe. In: SCHULZE, E.-D. \& CALDWELL, M.M. (Eds.) Ecophysiology of photosynthesis. Springer, Berlin, Heidelberg and New York, 1995. p 463-490.

KÖRNER, C.; SCHEEL, J.A. \& BAUER, H. Maximum leaf diffusive conductance in vascular plants. Photosynthetica 13:45-82, 1979.

KOZLOWSKI, T.T. \& PALLARDY, S.G. Physiology of woody plants. Academic Press, San Diego, 1997. 411p.

KRAMER P.J. \& KOZLOWSKI, T.T. Physiology of woody plants. Academic Press, New York, 1979. 811p.

LARCHER, W. Physiological plant ecology. Springer, New York, Berlin and Heidelberg, 1995. 506p.

LIMA, J.D.; DA MATTA, F.M. \& MOSQUIM. P.R. Growth attributes, xylem sap composition, and photosynthesis in common bean as affected by nitrogen and phosphorus deficiency. Journal of Plant Nutrition, 23:937-947, 2000.

PEARCY, R.W. \& EHLERINGER, J. Comparative ecophysiology of $\mathrm{C}_{3}$ and $\mathrm{C}_{4}$ plants. Plant, Cell and Environment, 7: 1-13, 1984.

POORTER, H. \& EVANS, J.R. Photosynthetic nitrogen-use efficiency of species that differ inherently in specific leaf area. Oecologia, 116:26-37, 1998.

PRADO, C.H.B.A. \& MORAES, J.A.P.V Photosynthetic capacity and specific leaf mass in twenty woody species of Cerrado vegetation under field conditions. Photosynthetica, 33:103-112, 1997.

REICH, P.B.; UHL, C. \& WALTERS, M.B. Leaf lifespan as a determinant of leaf structure and function among 23 tree species in Amazonian forest communities. Oecologia, 86:16-24, 1991. 
REICH, P.B. \& WALTERS, M.B. Photosynthesisnitrogen relations in Amazonian tree species. II. Variations in nitrogen vis-a-vis specific leaf area influences mass- and area-based expressions. Oecologia, 97:73-81, 1994.

REICH, P.B.; WALTERS, M.B.; ELLSWORTH, D.S.; VOSE, J.M.; VOLIN, J.C.; GRESHAM, C. \& BOWMAN, W.D. Relationships of leaf dark respiration to leaf nitrogen, specific leaf area and leaf life-span: a test across biomes and functional groups. Oecologia,114:471-482, 1998.

SAGE, R.F. \& REID, C.D. Photosynthetic response mechanisms to environmental change in $\mathrm{C}_{3}$ plants. In: WILKINSON, R.E. (Ed.) Plant-environment interactions. Marcel Dekker, New York, 1994. p 413-499.
SARALABAI, V.C.; BOLSTAD, P.V. \& VOSE, J.M. Plant responses to high $\mathrm{CO}_{2}$ concentration in the atmosphere. Photosynthetica, 33:7-37, 1997.

WOODWARD, F.I.\& SMITH, T.M. Predictions and measurements of the maximum photosynthetic rate, $\mathrm{A}_{\max }$, at the global scale. In: SCHULZE, E.-D. \& CALDWELL, M.M. (Eds.) Ecophysiology of photosynthesis. Springer, Berlin, Heidelberg and New York, 1995. p 491-509.

ZISKA, L.H. \& BUNCE, J.A. Influence of increasing carbon dioxide concentration on the photosynthetic and growth stimulation of selected $\mathrm{C}_{4}$ crops and weeds. Photosynthesis Research, 54:199-208, 1997. 